\title{
Planning for the unplannable: Responding to (Un)articulated Calls in the Classroom
}

\author{
Tanja Westfall-Greiter \& Johanna F. Schwarz, Center for Learning Research, School of \\ Education at the Leopold Franzens University of Innsbruck, Austria \\ E-Mail: tanja@mehralssprache.eu, johanna.schwarz@uibk.ac.at
}

\begin{abstract}
In this paper, the authors explore the pedagogical call as an articulated or unarticulated appeal from children in classroom settings and the many facets of pedagogical responsivity as they in vignettes stemming from a research project, funded nation-wide in Austria. While instruction can be planned, the pedagogical call can be understood as an appeal that occurs in medias res, in the midst of an event in the pedagogical situation, and can at best be anticipated. This dilemma of planning for the unplannable is constitutive of the pedagogical relation and addressed in the discourse regarding pedagogical tact in both North America and Europe. In seeking to gain insight into educational processes and learning through the lived experiences of 5th-grade students in Austria's "New Middle School" reform pilot, researchers were faced with a similar dilemma: How to capture the experiences of others, of children at school in medias res? The authors therefore provide background to their vignette research as a framework for their readings oriented to the pedagogical call as they arise in two vignettes. While articulated calls, and articulated responses, tend to be more straightforward, the authors address the difficulty of recognizing an unarticulated call of which the student is unaware, as well as recognizing no response as a response on the part of the teacher. Refraining from judgment as to the pedagogical quality of the teachers' actions, the authors conclude by addressing two critical aspects of the discourse on pedagogical tact driven by the principle of individuality: the underlying assumption that the other can be understood and the inherent concept of the pedagogical situation as one-to-one contact, the former ignoring the inaccessibility of the other and the latter neglecting the institutional laws that govern school reality.
\end{abstract}

\section{Arising to the pedagogical call}

The German educator Jakob Muth published his little known monograph on pedagogical tact in 1962. Similar to Max van Manen (1991), who views pedagogical tact as a specific way of being with children and youth (p. 11), Muth systematically explores the nature of pedagogical tact as the constitutive element of the pedagogical relation. To gain insight into tact, the teacher must be "caught in the act," for tact reveals itself in the act of being tactful. It cannot be planned but rather occurs in response to the other in a pedagogical moment. For Muth (1962), the heart of the matter is the nature of response particular to pedagogically tactful action, which is:

nothing more and nothing less than the response to an appeal, which like a question arises like a call to the teacher as it would to anyone in any interpersonal encounter. This call cannot be chosen or sought, one can only 
withdraw from it. He who responds to the arising call, however, is bestowed with humanity. (p. 72) ${ }^{1}$

Arising to the pedagogical call amounts to no less than being human. Muth's conception of humanity showing itself in the response to an appeal reminds us of Lévinas' (2002) face-toface and Bakhtin's (1981) dialogic responsivity. If tactful action is initiated by a call in the midst of an event (in medias res) in the pedagogical relation and such moments are essentially unplannable, the question arises as to the function and purpose of instructional planning.

Muth (1962) attends to this paradox of praxis and argues that careful preparation combined with a "deep affectation" by the subject enables the teacher to be flexible during instruction, assuming she has committed herself to the apparent insecurity of the teaching situation. This "apparent" insecurity is actually the source of true security in the pedagogical relation. By anticipating the unplannable, the teacher is able to respond in the act of teaching and change direction if and when called upon to do so by the appeals of children, "through their questioning glance and their facial expression, through their objections, perhaps also through their lack of attention, quasi through the "experience of the experience of the other"' (Muth 1962, pp. 84-85). Here Muth points to the moment of amazement when teachers realize upon later reflection they were "so clearly in a dialogue - albeit speechless - with the children, [were] so very present in the full present of the moment" (p. 85) that she deviated from her plan without noticing and without compromising the success of her teaching. Muth (1962) concludes: "often, the success of teaching occurs only when the teacher recognizes the opportunity of the moment and deviates from a planned route, when he musters the courage to act pedagogically tactfully" (p. 85).

In this paper, we explore the pedagogical call as an articulated or unarticulated appeal from children in classroom settings and the facets of pedagogical responsivity as they appear in vignettes stemming from a research project, funded nation-wide in Austria. In seeking to gain insight into educational processes and learning through the lived experiences of 5thgrade students in Austria's "New Middle School" reform pilot, which has since led to a mandated school reform, we as researchers were similarly faced with the dilemma of planning for the unplannable. How can we capture the experiences of others, of children at school in medias res? How can we see what is there, rather than what we assume is there? How can we manage to capture more than we see? We provide background to our research methodology and community as a framework for our readings of two vignettes. While the vignette research primarily focuses on students' learning experiences, for the purposes of this article, our attention in the readings is directed to the pedagogical call. We will then explore more concretely this phenomenon in the relation between teachers and students in the context of institutionalized schooling. While articulated calls tend to be straightforward, we will show how recognizing an unarticulated call of which the student is unaware requires a great deal of interpretation on the part of the teacher. We conclude by addressing two critical aspects of the discourse on pedagogical tact: the underlying assumption that the Other can be understood and the inherent image of the pedagogical situation as one-to-one tutoring which tends to ignore the institutional laws that drive school reality.

\section{Phenomenologically oriented vignette research}

In light of our inquiry goals, the aim of our data collection was to tactfully access and capture in writing the fundamentally inaccessible, the lived experience of children at school. Early on it became clear that a phenomenological orientation would not only be preferable but necessary. Data collection was guided by the principles of intropathic sensing (Därmann \& Busch 2007) and describing what is given rather than constructing or forming the real. As Merleau-Ponty (1958) articulates it at the beginning of his preface to the Phenomenology of 
Perception, "(p)henomenology... tries to give a direct description of our experience as it is, without taking into account its psychological origin and the causal explanations which the scientist, the historian or the sociologist may be able to provide" (p. vii). Echoing Edmund Husserl's (2009) call to attend to "the things themselves," phenomenologist and pedagogue Käte Meyer-Drawe, one of our research mentors, described our discourse as one which springs forth from the things themselves rather than by our assumptions, theories and judgments about them (Von den Sachen her, statt über die Sachen).

Vignettes, dense narratives of poignant experiential moments, have become the central research instrument to explore this. Initially inspired by van Manen's (1990) "anecdotes of lived experience," the vignettes are differently crafted. As a form of literary non-fiction they differ from anecdotes in the van Manen tradition in that they do not derive from recall in interviews and conversations but from co-experiencing the experience of others in the field. Researchers are called upon to sense the lived experience of the students in medias res, as they are happening, to "experience the experience of others" and be affected by it. ${ }^{2}$ They coexperience in the field, note details in their protocols, and then later write narratives of the experience. Researchers strive to capture empirical data which include pathic elements of the experience; thereby go beyond reconstructing an experience to recreating it, ensuring that the vignette remains accurate and true to the experience. The selection of poignant moments is an act of sensing on the part of the researcher, whose attention has been heightened by a corporeal expression of pathos, such as a flinch, a flow posture, or a pained facial expression. In short, the researchers respond to a call while in the midst of things. They might also sense a lack of pathos and attempt to capture an experience that did not yield dramatic expression, whereby special attention is also paid to corporeal expression: a sigh, a slouch, a head propped idly in a hand, or an empty gaze signifying a sense of absence.

The vignette isolates single experiential moments, marking them as significant, exposing them, and directing attention to them. Vignette research, as we have come to call it, entails an aesthetic sensibility. The vignette should not tell, but rather show. In so doing, it becomes telling. The vignette is tight but loose, inchoative in that it discloses the world in an encapsulated moment, which stands alone and in reference to itself, allowing a context to emerge and open to multiple readers and to multiple readings. Like experience itself, vignettes not only make meaning, they also make sense: Firstly in that the reader gains a sense of the experience, a feeling for the event and situation, and secondly, in Husserl's (1958) language, in that sense is always a "pointing to" (Verweisung auf). As Bernhard Waldenfels (2002) notes, "we see in a particular situation means paradoxically that we always see more than that which we see" (p. 70; 138). Vignettes, like experience, are grounded in surplus (Überschuss), the impossible plurality and excesses of life. There is always more announcing itself than that which is explicitly there.

The "language speaks the phenomenon rather than of it" as van Manen (1990, p. 13) writes, which poses a particular challenge to the writer, who strives to describe and capture the pathic moments taken from the stream of experience and write accurately and concretely, but also movingly. As a form of literary non-fiction, the vignette should read with deceptive ease. The seams should not show, the "language must not sweat," to use the words of Toni Morrison (see Taylor-Guthrie, 1994, p. 123). This literary quality in phenomenological texts is no coincidence. Merleau-Ponty likens phenomenological research to literature and van Manen, in keeping with the Utrecht School's emphasis on writing, has taken great pains to clarify the aesthetic quality of anecdotes of lived experience, describing them as "vocative" texts in which the sense is so strongly embedded that it is difficult to paraphrase or summarize (see van Manen, 2011).

It is worthy of note that this type of research may be questionable or even difficult to grasp for researchers in other traditions or disciplines. In the introduction to their volume on pathos, the German phenomologists Kathrin Busch and Iris Därmann (2007) expose the 
marginalization of pathos in European philosophical and research traditions. They argue that pathos has been expelled from philosophical and scientific inquiry and ascribe this to the attempt to escape facing happenstance as constitutive of experience. The Greek $\pi \alpha$ ó $\theta \varsigma$ (pathos) means "I feel, I suffer;" the subject is entangled with the lifeworld and subjected to it.

As our work in this project has evolved, we have referred to the exploration of a vignette in various ways, moving from "interpreting" to "analyzing" to "explicating," all of which include some truth about the process but none of which articulate it fully. As we explored what it means to write and read poignantly, we arrived at the terminology we currently use: we call our work with the vignettes a "reading," in which the reader engages with the text and senses her way through the experience, a pointing to rather than pointing out (see Finlay, 2009 , p. 11). In the practice of vignette reading, the researcher is academically rigorous in exercising restraint and strives to maintain the openness, re-searching as a reader, noticing what is there, what she has not seen before or what she sees in a new light, mindful of and opening to the "more" of the experience. The process is at once a closing in on and opening to, a peeling off and adding of layers.

As phenomenologically oriented researchers we are actively passive, purposefully refraining from explanations that are definite and final. Like Michelangelo's finger (Tallis, 2010), a reading comprises profoundly human gestures pointing to something, be it a turn of phrase, a naming, an association, an image, a metaphor, a question, a particular focus or a reference. Similarly, the articulated or unarticulated calls of children, appeals that can be understood as gestures, which must be recognized, point to the more or less tactful responses of their teachers. Particularly challenging is to differentiate the response of no response: Has the teacher chosen to tactfully hold back or has the appeal gone unheard or even purposely ignored, subordinated to some other need?

\section{Reading the pedagogical call}

Currently, our collection for this research project comprises over 70 vignettes of the lived experiences of children in their first year of middle school (Schratz, Schwarz, \& WestfallGreiter, 2012). For the purpose of this contribution, we present two vignettes from the particular angle of the pedagogical call. We begin with a vignette capturing Sebastian's experience, a vignette that stands out precisely because of the pedagogically tactful manner with which his teacher responds to him during the lesson. Unfortunately, most of Sebastian's teachers have ascribed to him negative labels, from "slow learner" to "minimalist," and their responses to him seem to be derived from these (mis)conceptions. As we shall see, this teacher seems to have refrained from such prejudgments, or at least suspends them in order to respond to him regardless of any notions she might have of who or what Sebastian might be.

Vignette 53

Sebastian is sitting with Silas at a table in the row by the windows and is working on the task cards for Expanding and Fractions. He raises his hand: The teacher notices and answers with eye contact and a whispered, "I'm coming!" In a few minutes she is at his desk and explains, asks questions, makes suggestions, questions, demonstrates, explains. Sebastian follows her intensively with his eyes, the pencil in his hands. Once he laughs aloud and beams. He goes back to his working on his calculations alone and soon he falters. The teacher appears back at his desk and advises, "Try giving your head a shake. Then it'll come!" He sits with slumped shoulders, stretches his right foot out, his left hand resting on his thigh. He counts the number of squares in the illustration with his pen, the finger of his left hand plays with his 
lips. He writes numbers in blanks. He counts the number of squares again, wipes invisible eraser crumbs from the worksheet, erases. He looks at the board in the front, where a sample problem and solution are written. "Ah!" he says once again in response to his teacher's tip: "You've picked out the difficult task cards. No wonder you can't figure it out right away. It's really difficult. Try the other easier task cards later, just to check!" (Schratz, Schwarz \& Westfall-Greiter, 2012, p. 80)

Sebastian raises his hand, a common call in the classroom, non-verbal but nonetheless articulated. His teacher sees his hand and responds with eye contact and a whispered, "I'm coming." This is a good feeling; a reassurance that help is on the way, of knowing one is about to be rescued. How much time elapses between his call and her help? It seems to be just a short gap, but how long does it feel to Sebastian? Does he stop and wait for her or does he keep on trying? In any case she is at his side within a few minutes and she helps in different ways, does her best to support him through the struggle, explaining, asking questions, making suggestions, posing more questions, and showing further examples. So much attention, so much of being taken seriously! No wonder that Sebastian focuses on her, is engaged in, almost entranced by their conversation. He smiles. Then he is on his own and again the going gets tough. His flow is interrupted, or perhaps never really gets started.

Pedagogically we ask: How did his teacher notice? Was she keeping an eye on him, did she notice a sinking of his shoulders, a frustrated sigh? Sebastian does not raise his hand again, he does not call her by name, but she is back at his desk with advice at the ready, playful, light and encouraging. "Just give your head a shake and it will come!" Sebastian's teacher seems to try to alleviate the moment and bridge the difficulty, to encourage Sebastian to believe as she does that the answer he seeks is within him. A powerful pedagogically oriented message is clothed in this playfulness, even if it does not seem to empower him in the moment. However, it is evident she has confidence in his ability, in him. It is all already there within him if he can just manage to shake it loose, to release it. On his own again, though, he worries over the task, tries and tries again, but it all seems to be uncertain, fragile, tentative, blocked, strained, hectic. Is it panic he feels? Frustration? He seems to be at a loss, for he seeks the solution in a new place outside of himself, directs his gaze to the example on the board. Again his teacher has apparently kept her eye on him, has sensed this unarticulated call for help and takes up Sebastian's problem anew, gives him a tip. It almost feels like she is letting him in on a secret: He has chosen the most challenging tasks. Aha! No wonder it is so hard!

Will Sebastian stick with the challenge although he is struggling, in over his head? Will he continue to wrestle with the problem or will he turn to an easier task just to be sure of his ability? Will he accomplish his goal with an easier task card and be satisfied, check the goal off his list, be done with it, or will it give him new confidence to take on the difficult one again? His teacher has not advised he change directions and take the easy path, she only suggests a detour to double-check with the easier task cards, just to be sure. She seems to sense that he may need more practice on safer ground before he takes on the difficult tasks, but never once does she indicate that he does not have the potential to achieve even the challenging ones, if not now then later, someday. Why does she let him struggle so long? Was she keeping watch, hoping that he would manage so that she could surprise him with the news that he had started with the highest-level tasks? Or is she simply giving him time to discover the consequences of his own choices? Whatever the case, Sebastian's teacher sees him, literally and figuratively. He receives recognition in this classroom, recognition of who he is, even who he can become, rather than recognition for an accomplishment or, as would be the case here, notice of failure. She keeps her eye on him and the challenge he has set for himself, fully aware that he might not be able to meet it, focusing on his ability rather than inability, on 
his potential rather than his shortcomings. She refrains from intervening uninvited, gives Sebastian the space he needs to experience difficulty and try to overcome it on his own. How difficult was it for her to hold back, to let him struggle? How did she sense when to go to him, how to nudge him along?

The teacher's responses to Sebastian's calls are articulations of pedagogical tact. In this vignette we see tact as the practice of being oriented to others, responding flexibly to the unplanned, preserving the child's space, strengthening what is good, sponsoring personal growth and learning - all aspects of tact which van Manen (1991) explores as essential structures of this particular way of being with children. Both Sebastian's calls, and his teacher's responses, are mediated through speech, glances, and gestures. We sense the situational confidence of the teacher as she observes Sebastian from afar. This vignette seems to be an ideal exemplar for revealing how a teacher in a pedagogical relation to a boy at school responds tactfully to his articulated and unarticulated calls. She is in a verbal and nonverbal dialogue with him.

A very different situation is captured in the next vignette. While in the first one the teacher vividly responds to Sebastian's articulations of need this one reveals Roland's unarticulated calls and the teacher's response to them.

Vignette 17

The fifth period, nearly the end of the school day, begins with sustained silent reading. Everyone seems to know what they are supposed to do. Without much further ado, Roland, sitting alone in the last row at the back of the classroom, turns around and stretches to take a Mickey Mouse comic book from the shelf behind him. He does not need to get up at all, his deck so close to the wall at the back. He places the comic on his lap, closes in on it, rests his head on his right elbow on the bench and is soon lost in his reading. Again and again, he chuckles out loud, once he exclaims, "Super!" Occasionally he turns the pages back and forth. In the meantime Mrs. Redel, the teacher, takes care of organizational matters with some of the students. After a quarter of an hour her voice, loud enough for everyone to hear, penetrates the working noise in the room. "Close your books, put them aside, and open your notebooks!" she demands. Roland is still immersed in his reading and seems not to hear anything. Everyone else is following her instructions, but not Roland. The teacher approaches him and asks if he has heard what she said. Without hesitation he retorts sullenly, "Close your books, put them aside, and open your notebooks!" He makes a face as he closes his comic book. (Schratz, Schwarz \& Westfall-Greiter, 2012, pp. 64-65)

"Why do you interrupt? Can't you see I'm reading?" This might have been Roland's response had he been called on directly by his teacher, asked about his joyful involvement with Mickey Mouse. Roland is cooperative, does what he is asked to do at the beginning of this lesson. He uses the period of sustained silent reading well, limited in time as it may be. By placing the book on his lap and closing in around it, he creates some personal space for himself in the public space of the classroom. In this intimate space, he encounters a world that makes him smile, verbally articulate his pleasure, go back and forth among the pages, as if he does not want to miss any of its subtleties. He is so deeply engaged in the adventures of Mickey's world that he overhears the first call of the teacher to return to less appealing lesson routines, or so it seems. Her direct address makes him respond; sullenly he repeats her words. He has heard her after all, can cite verbatim. Task fulfilled, chore done, time to move on. She does not inquire about his reading experience, does not ask what spoke to him in the text, what 
made him laugh, speak out loud and turn the pages back and forth. She does not ask what insights he has gained or what pleasures he found in Mickey's world. What wonders could have been discovered here had the teacher wondered what made Roland wonder in his reading? Did she even notice his engagement?

What is Roland's call in this scene? Is it his silent resistance to the interruption, to the call to return to the routines of the lesson, to the command demanding attention? That Roland continues reading, although the teacher has summoned everyone to turn to the next sequence of the lesson, could be understood as an unarticulated call: Please, let me read on, let me continue, wait for me until I am ready to re-enter the school world! If you ask me nicely, I will tell you about the treasures and pleasures I found. Rather than a call to respond tactfully to his immersion in the comic book, the teacher seems to interpret Roland's absentmindedness as disobedience. It is a small wonder that Roland can delve into reading so quickly, and so deeply, despite the distractions in the room and then be so immersed, that he dreads leaving the realm of pleasure he found in the pages of his book.

Teaching is no easy task. In their attempt to use lesson time well, teachers are often running against the clock while trying to manage the challenge of attending to the articulated calls of 25 children, not to mention the unarticulated ones. Could Roland's silence, his lack of response to the teacher's instructions be understood as a call? His behavior is unwanted, unacceptable for his teacher, this she makes clear with her intervention as she addresses him directly. Has he heard her? Evidently he has, although his actions did not show it. And beyond the words he transmits further information. His response is a retort, a sullen recitation of the teacher's words. Is this sullenness expressed in his body language as well? What message is written on his face as he closes his comic book? Is it a last appeal, which goes unheard or is it simply resentful compliance, which can be read in his face?

\section{Caught between teaching and schooling: The dilemmas of pedagogical tact}

Both Sebastian and Roland are engaged in subject matter, Sebastian in math, Roland in reading. Both of their teachers respond to them individually and personally. While Sebastian's teacher seems to be focused on prolonging Sebastian's engagement, Roland's teacher appears to focus on switching his attention to something else. We sense aggression in this interruption, even find ourselves uncomfortable and irritated by it. Muth (1962) sheds light on this discomfort for he regards interrupting a child immersed in subject matter as contrary to pedagogical tact, going so far as to view it as hurting the child (p. 46). In his evocation of the in loco parentis relation between students and teachers, van Manen (1991) likens the status of teachers to that of parents. Like parents who must move their own children to switch their attention ("Lights out! Time to go to sleep!"), Roland's teacher seems to be focused on what needs to happen next in the class. It would be unjust to assume that this is not in Roland's own interest. Perhaps the next activity or topic is particularly important for him to master, perhaps he has struggled already and is dreading the work of learning. Reading could be his escape, his resistance to the hard work of learning, a barrier to his education, which must be overcome.

Tactful response to the pedagogical call materializes itself in concrete situations in which we are confronted by the Other caught in his or her own stream of experience: at risk, shaken, frustrated, but also immersed, concentrated, and absorbed in flow. Roland's posture, actions and verbalizations during reading could be recognized as an appeal for more uninterrupted time, a manner of sharing his pleasure, a signal that he is in his own world. His sullen repetition of the teacher's voice could be heard as evidence of injury, an articulation of being painfully torn away from the adventure with Mickey Mouse, a last appeal for more time to read. Discerning and deciphering a child's corporeal responses to what they encounter at school as unarticulated calls is an overwhelmingly complex task for teachers in a classroom. 
Teachers must divide their attention among twenty-plus students and attend to them individually while simultaneously keeping in mind the goals to be achieved within an allotted period of time. It also requires a specific pedagogical awareness, which comes to light in Vignette 73. Sebastian's teacher seems to appear at his desk out of the clear blue. She might have anticipated his articulated and unarticulated need for help, but she could not have planned for it. Was she so attentive because of the researcher in the room? Was she equally mindful of the other students' learning during this 50-minute lesson or was she primarily focused on Sebastian? We cannot assume that all of the children in Sebastian's class experienced this lesson as Sebastian did, nor can we assume that Sebastian's math teacher interacts with him in this manner in every lesson.

Muth (1962) highlights the importance of sensitivity or susceptibility to the other (Feingefühl) (p. 19) and van Manen (1991), while also emphasizing that the need for tact cannot be foreseen, considers how it can become a habit in the way teachers and other adults are with children, describing it as a style of being with students (pp. 120-121). Among the virtues crucial for the specific nature of the pedagogic relation Bollnow (1961) considers trust and belief in a child's capacity to be essential. Bollnow differentiates between trust (Vertrauen) as a moral, reciprocal concept demanding response, while confidence or belief (Zutrauen) ${ }^{3}$ relates to distinct ability in a positive sense, independent of a person's (re)action in a single situation. Unwavering faith in students' ability provides fruitful ground upon which they can grow; a lack of confidence will, as Bollnow argues, be detrimental for their development. Sebastian's has an uncertain gaze, which is taken up by his teacher. Yet she enters into dialogue with him, communicating with encouraging glances, words, whispered assurances and physical presence. She communicates her belief in him and admiration for his choice to stick with a difficult task. Is this a generalized belief she has in all of her students or is it specific to Sebastian? Is it her consistent style in dealing with the fundamentally unplannable?

\section{Challenges of attending to pedagogical text in institutional settings}

As we can see in these vignettes, tact is a social phenomenon in its articulation as sensitivity and restraint expressed and therefore revealed in contact with an Other, be it a teacher in contact with a student or contacts among peers (Muth, 1962, p. 20). Pedagogically, tactful teachers restrain themselves, sensing "when to pass over things, when to wait, when 'not to notice' something, [and] when to step back" (van Manen, 1991, p. 151). For Muth (1962), this active-passive disposition ought to refrain from measures intended to change students (p. 21). Yet we ought not overlook that both of these vignettes derive from institutional school settings, in which Wilfried Lippitz (2007) suggests pedagogical reality can be understood "as an active and reflective practice which arises, and is changed and maintained in systems of order" (p. 78). The school's mandate, often ignored in current European discourses on education and pedagogy linked to notions of "individualizing," is indeed to change the child, to make a student out of him or her (Lippitz \& Levering, 2002, as cited in Lippitz, 2007). Similarly, John Dewey (1916) sees school as a social organ and the process of schooling as a "shaping into the standard form of social activity" (p. 10). As Lippitz (2007) notes in his discussion of foreignness, school is in the business of normalization and does so "through exclusionary and homogenizing practices and processes" (p. 79). In response to this institutional goal and its counter-productive impact on the pedagogical relation, Carol Ann Tomlinson (2011), also a mentor in our work, calls upon teachers to "disaggregate "the students'," to consciously and tactfully recognize each as an individual in his or her own right. Käte Meyer-Drawe (2012a) explores a different perspective in her essay, "Imprisoned in the Everyday Lifeworld." She views shaking the students' habits, common understandings of the world, as well as confronting them with irritating and 
confrontational concepts as a fundamental contribution of school to student learning in order to help them escape what she calls their daily and milieu-specific routines.

Johann Friedrich Herbart (1964), who coined "pedagogical tact" in his first lecture on pedagogy in 1802, was a private tutor in privileged households and this experience has left its mark in his argumentation regarding the art of pedagogy. This image of one-to-one contact rather than one-to-twenty-five as is normal in school settings is still present today. It is no coincidence that the cover of van Manen's (1991), The Tact of Teaching, a painting from the $15^{\text {th }}$ century entitled "Grandfather and Grandson" by Ghirlandajo, seems a strikingly appropriate illustration to capture the essence of the subject. Yet, the image of one-to-one, of the older and wiser interacting with the young and becoming in the intimacy of home, is difficult to reconcile with the institutional context of school. The image operationalizes the principle of individuality in a manner, which is not practicable. Concepts of individualizing instruction stemming from this idea bring forth several dilemmas, which not only overwhelm teachers but also create a polis desiderata of little practical relevance in the classroom setting, or worse, lead to a violation of the individual by presuming rather than remaining open to the person in front of them (Schratz \& Westfall-Greiter, 2010).

Beate Wischer (2012) likens the notion of individualization in current European discourse to a smoke bomb that disguises the reality of school as institution. To leave school's institutional grammar, structure and goals unconsidered limits the discussion to the functional logic(s) of organized educational processes and ignores school and organizational theoretical perspectives. Roland does not have the power to disobey his teacher although she may be acting tactlessly. Indeed, he himself may be acting tactlessly in holding back the group. Nor can he reproach his teacher for imposing planned tasks that in, of themselves, show little pedagogical tact, although they reflect the rhythmic tact of the school day. Essentially, he has been asked to dive into a book and engage in reading, but keep it short. He should stay on task for the fifteen minutes, even if others in the room are talking and moving about. When the fifteen minutes are over, he should immediately redirect his attention when told to do so. The teacher seems to articulate in her actions, "I do not see you, I see the class and expect it to work as a whole. Your needs are subject to the group's needs, which are subject to mine, which are subject to the curriculum and the institution." His teacher's actions are understandable in this long chain of authority. She is acting on behalf of the institution when she insists upon obedience and cooperation, and she is acting with the interests of the class in mind, insofar as there is a lesson to be covered in limited time.

Nonetheless, we cannot help but wonder how much confidence Roland (still) has in his teacher to provide him with a challenging, but supportive learning environment. What does it feel like for him to act in unison with his classmates, to be seen as part of the whole, rather than as himself as a whole? In her reading of this vignette, Carol Ann Tomlinson writes:

I'm glad Roland had a chance to lose himself in Mickey's world - that he was able to read something that really engaged him.... I understand that he may not have heard the voice from the world he didn't want to re-enter-or that if he did hear it, he may elected to have switched it off. I also understand the teacher who feels a need to move the class in a new direction. I just wish she might have called him back more gently, more graciously, so that the good time of reading didn't have to end on a sour note. (Schratz, Schwarz \& WestfallGreiter, 2012, p. 112)

In her work on differentiated instruction, Tomlinson (2003) emphasizes "responsive teaching" which is respectful of the individual and mindful of educational goals. The differentiated school is one which upholds the values of individuality and academic diversity by responding to the needs of all learners. This responsivity in a school culture and the classroom requires 
careful consideration of institutional factors, which resist change and are barriers to these goals (Tomlinson, 2008).

According to Muth (1962) the "individuality principle" underlying concepts of responsive teaching and pedagogical tact can be traced back to Rousseau and Pestalozzi and it is the principle, which enables one to experience the experience of the other. A tactful teacher is one who attempts to do justice to the child's individuality, a case-specific matter that cannot be generalized or abstracted (Muth, 1962, p. 49). He addresses three aspects of the individuality principle in the day-to-day work of a teacher: on the levels of school, classroom, and method. Firstly, a child should not be put to shame at school for being different, whether arriving late, dressing inappropriately, or not paying for the class trip on time, for these matters are beyond the responsibility of the child. Muth contends, "each child who is already aware of his family's material poverty is hurt when this intimate sphere is violated" (p. 50). In the classroom, the second aspect, teachers are also mindful of the individual, which can be difficult to do in a same-for-all lecture mode in which the teacher's teaching is dominant, for it tends to reduce the individuals to sameness. Likewise, when a teacher insists upon a single method and holds it above all else, she is negating the individuality of the students, the contingent character of teaching and learning and the irregularities that occur during learning. (pp. 50-52)

Mike Rose (2009), in his musings and critical perspectives on school, notes that he has "experienced classrooms as both places of flat disconnection and of growth and inspiration" and that "this mix has proved invaluable" to him as a teacher (p. 33). Is pedagogical tact an element of a classroom of growth and inspiration? Acutely aware of school as an institution, Rose argues:

it is our experience of an institution that determines our attitude toward it, affects what we do with it, the degree to which we integrate it in our lives, into our sense of who we are. We need to pay attention to the experience of going to school. (p. 32)

It seems particularly worthy to consider what contributes to experiences of classrooms as places of growth and inspiration, but are there also lessons to be learned in and through less positive experiences? The primary interest of our research is the experience of learning in school. According to Meyer-Drawe (2008, p. 15) we do not only gain a new perspective when we learn but must let go of an old one. If in this understanding the experience of learning is initiated at that moment when the old no longer serves us and the new is not yet available, this is no comfortable state. Thus, it could be articulated in pondering looks out of windows, in hesitance or reluctance, in worried or frustrated faces, through exclamations of exasperation and uncertainty. Michael Schratz (2009) calls us to probe what is happening "lernseits" of instruction, on the students' end, in the space between their learning and the teachers' teaching?

Current mainstream empirical research in education is focused on optimizing processes of institutionalized education to achieve the best possible measurable learning results, a gap which our research into learning as experience attempts to fill. The assumption that teaching and learning stand in a causal relationship to one another relegates the events that occur on the students' end to backstage, where they remain in the dark. Konstantin Mitgutsch (2008) points to the "shadowy existence" of the learning experience (p. 263) and Meyer-Drawe (2010) argues that learning in its nascent state, the pedagogically significant moment, is rarely considered: "Learning itself comes predominantly into view in the form of results, as in longterm neuronal connections from a neuroscientific perspective or in the building of memory within the framework of cognition theory and its assumptions. The process itself withdraws from our attention both lifeworldly and scientifically" (p. 9) Rather than focus on measurable 
results of learning once the experience has been lived through and referring to inventories of competencies or outcomes as measures, we attempt to unfold learning as experience: learning as asking, answering, struggling, guessing, attempting, practicing, repeating, searching, double-checking, and so on.

Learning as experience rather than learning as a product of experience reveals how learning and teaching processes are irrevocably intertwined and codetermined (Meyer-Drawe, 2008; 2010; 2012a; Schratz, 2009; Schratz, Schwarz \& Westfall-Greiter, 2011;). The classroom becomes a place where learning opportunities or pedagogical moments occur rather than where teaching measures are implemented. Meyer-Drawe's (2008) theoretical work in the phenomenology of learning defines learning as an experience, which is "an idiosyncratic entanglement in a world to which we respond in that we take on its articulations" (p. 16) and she argues that learning

in this sense cannot be fully instructed. It is an event. That does not, however, make a teacher superfluous. The more he or she knows about the contingent nature of learning, the more he or she will be able to exploit the opportunity of the moment. (p. 16)

If we scarcely grasp the phenomena of learning, how can teachers possibly initiate, foster, support or bring to closure learning experiences (Meyer-Drawe, 2008, p. 209) in an institutionalized setting?

While Muth (1962) consistently considers the institutional context in which teachers teach, it is these aspects of praxis - the pedagogical relation between teachers and students as well as the relation to specific subject content-which appeal to the values held by many teachers, teacher educators and researchers. Teaching is a calling in itself, which is energized by the image of one-to-one education and making a difference in the life of a student. The danger lies in limiting discourse to these ideals. Wischer (2012) addresses precisely this field of tension between identification with ideals and the "grammar" of the institution, pointing out that school as a system is contrary to the principle of individuality in that it by definition subordinates individuals and is at the very least indifferent to their subjectivity, as can be seen in its most basic of structures, whether compulsory attendance, classification by age, or the subject canons. The result is the burden of the "black box of the private tutor" (Wischer, 2012).

For pedagogical calls to be heard, teachers must have a particular predisposed receptivity in order to sense the experiences of others. A "call" is a sound and therefore must be heard, but the pedagogical appeals of children must often be seen or sensed in the gestures, postures and facial expressions of students. This is a nearly impossible task, and one must be wary of presuming one can fully understand the other. As Meyer-Drawe (2012b) counters, if the child does not even know where he or she stands, how can an educator possibly know? Further, it seems that the institution of school gives license to be non-responsive in the interest of institutional goals. Lévinas (2002), who spent his life seeking the foundation of ethics and was driven by his analysis to move beyond existence, would be left unsatisfied by this excuse. As he writes, in his characteristically poetic diction, in the Foreword to Humanism of the Other:

Between the one that I am and the other for whom I answer gapes a bottomless difference, which is also the non-indifference of responsibility, significance of signification, irreducible to any system whatever. Non-in-difference, which is the very proximity of one's fellow, by which is profiled a base of community between one and the other, unity of the human genre, owing to the fraternity of men. This proximity does not mean a new 'experience' opposed to the experience of objective presence, an experience of 'thou' produced after, or 
even before, the being's experience of an 'ethical experience' in addition to perception. No, it means casting doubt on EXPERIENCE as source of sense. (Lévinas, 2002, p. 6)

Lévinas (2002) reminds us that it is impossible to understand the other, separated as we are by a bottomless difference. Experience itself may not make sense, may not be the source of all knowledge. Is it perhaps non-indifference, which enables a teacher to be human, responsive, tactful in an impersonal system?

\section{Ethical dimensions in practicing the pedagogical tact}

While this question goes beyond the scope of this paper, we would like to note the differences between our situation as researchers and the situation of the teachers in these vignettes. We are mindful that we enjoyed the luxury of attending to two children in a class of twenty-five. We had the privilege of encountering them as subjects free from the institutional restrictions and expectations that a teacher must navigate. We could attempt to open to their experience so that we could be affected by it, capture it first corporeally and then in words. While we are able to reveal and share our experiences of these experiences of children in vignettes and re-search them again and again to gain insights into educational processes and learning at school, it is of the utmost importance that we tread carefully, refraining from seeking what we want to find and drawing quick conclusions, from romanticizing the ideal, and damning those who fail to meet it. We must keep in mind the sheer impossibility of responding simultaneously to the appeals of several children at once, nonetheless of recognizing those unarticulated calls of which even the students themselves are unaware.

Virtues such as faith and values such as tact belong to the domain of ethics, which may very well go beyond the limits of experience if they are to be finally valid beyond the restrictions of an institution. In the post-Holocaust Europe of the 1960s, Muth (1962) was highly sensitive to the potential of the individual to abdicate his or her responsibility in the name of an institution. Early in his treatise on pedagogical tact he addresses teachers as part of the school system: "Whoever surrenders his individuality to uniformity and is merely the typos of an 'organization' has displaced the possibility of tactful action no differently than one who withdraws from any form of responsibility in the disintegration of human relations" (p. 8). Teachers are called upon to be tactful mediators between an impersonal system, which subordinates its subjects, and the persons, whom they as actors in the system are to educate. Yet, the profoundly subjective nature of educational processes cannot be denied: "Growth is not something done to them; it is something they do" (Dewey, 1916, p. 42). Each pedagogical call provides evidence of this simple fact, a daily reminder of the inherent dilemma of the pedagogical situation in school.

Van Manen (1991) opens a possibility for addressing this dilemma of being tactful in an institution which is not tactful per se: fostering the habit of pedagogical tact, developing a particular style that allows for responding to the individual as respectfully and educatively as possible in any one unplanned but nonetheless generally anticipated moment. Tomlinson's exhaustive efforts to guide not only today's teachers but also school leaders in creating responsive environments to ensure access to education to each student is ground-breaking in its consistent consideration of the institutional factors which may prohibit honoring the individuality principle in the practice of teaching. It is likely that their work will lead to memories of the classrooms as places of growth and inspiration to which many educators and researchers aspire, but it is also clear that there is no blueprint for designing one experience for all. The phenomenon of the pedagogical call can be understood as a general appeal to plan the plannable and expect the unexpected. 


\footnotetext{
${ }^{1}$ This and all other translations from the German to the English are the authors'. The extensive references to Muth (1962) and Herbart (1802/1964) intend to draw on the originals.

${ }^{2}$ In the initial phase of our research project, we called this "shadowing" but as we examined more closely the research experience, we recognized it as intropathy (Einfühlung). Einfühlung poses a philosophical problem, most notably in the work of Husserl, Merleau-Ponty and Lévinas, which cannot be addressed adequately in the scope of this paper. For a strikingly compact summary of the discourse on intropathy, see Note 33 to page 106 in: Lawlor, L. (2003) Thinking Through French: The Being of the Question. Bloomington: Indiana University Press.

${ }^{3}$ While Zutrauen has been translated into English as "confidence", we consider "belief in" a more adequate translation.
}

\section{References}

Bakhtin, M. M. [1930s] (1981) The Dialogic Imagination: Four Essays. Ed. Michael Holquist. Trans. Caryl Emerson and Michael Holquist. Austin and London: University of Texas Press.

Bollnow, F. O. (1961). The pedagogical atmosphere. Retrieved from http://ejournals.library.ualberta.ca/index.php/pandp/article/viewFile/15111/11932

Busch, K., \& Därmann, I. (2007). »pathos«. Konturen eines kulturwissenschaftlichen Grundbegriffs. Bielefeld: transcript Verlag.

Dewey, J. (1916). Democracy and education: An introduction to the philosophy of education. New York: The Free Press.

Finlay, L. (2009). Debating phenomenological research methods. Phenomenology \& Practice, $3(1), 6-25$.

Herbart, J. F. (1964). Die ersten Vorlesungen über Pädagogik (1802). In Kleinere pädagogische Schriften (pp. 121-131). Düsseldorf: Küpper.

Husserl, E. (2009). Ideen zu einer reinen Phänomenologie und phänomenologischen Philosophie. Stuttgart: Felix Meiner.

Husserl, E. (1985) Erfahrung und Urteil. Untersuchungen zur Genealogie der Logik. Redigiert u. hrsg. von L. Landgrebe. Mit Nachwort und Reg. Von L. Eley. 6., verb. Auflage, Hamburg: Felix Meiner.

Lawlor, L. (2003). Thinking through French: The being of the question. Bloomington: Indiana University Press.

Lévinas, E. (2002). Humanism of the other. Urbana and Chicago: University of Illinois Press.

Lippitz, W., \& Levering, B. (2002). And now you are getting a teacher with such a long name. Teaching and Teacher Education, 18(2), 205-213.

Lippitz, W. (2007). Foreignness and otherness in pedagogical contexts. Phenomenology \& Practice, 1(1), 64-81.

Merleau-Ponty, M. (1958). Phenomenology of perception. London: Routledge. 
Meyer-Drawe, K. (2008). Diskurse des Lernens. Munich: Wilhelm Fink.

Meyer-Drawe, K. (2010). Zur Erfahrung des Lernens. Eine phänomenologische Skizze. Santalka Filosofija, 18(3), 6-16.

Meyer-Drawe, K. (2012a). Gefangen in der Alltagswelt: Schattenseiten des selbstorganisierten Lernens. In B. Schäfer; M. Schemmann \& O. Dörner (Eds.) Erwachsenenbildung im Kontext. Theoretische Rahmungen, empirische Spielräume und praktische Regulative (pp. 31-41). Bielefeld: W. Bertelsmann.

Meyer-Drawe, K. (2012b, January). Treffpunkte oder über die Täuschung, Schülerinnen und Schüler dort abholen zu können, wo sie sind. Keynote presented at the Symposium on Learning and Leadership in Honor of Michael Schratz's $60^{\text {th }}$ Birthday, Innsbruck, Austria.

Mitgutsch, K. (2008). Lernen durch Erfahren: Über Bruchlinien im Vollzug des Lernens. In K. Mitgutsch, E. Sattler, K. Westphal \& M. Breinbauer (Eds.). Dem Lernen auf der Spur: Die pädagogische Perspektive (pp. 263-277). Stuttgart: Klett-Cotta.

Muth, J. (1962). Pädagogischer Takt: Eine Monographie einer aktuellen Form erzieherischen und didaktischen Handelns. Heidelberg: Quelle \& Meyer.

Rose, M. (2009). Why school? Reclaiming education for all of us. New York: New Press.

Schratz, M. (2009). "Lernseits" von Unterricht. Alte Muster, neue Lebenswelten - was für Schulen?. Lernende Schule, 12(46-47), 16-21.

Schratz, M., \& Westfall-Greiter, T. (2010). Das Dilemma der Individualisierungsdidaktik. Plädoyer für personalisiertes Lernen in der Schule. Journal für Schulentwicklung, 14(1), pp. 18-31.

Schratz, M., Schwarz, J. F. \& Westfall-Greiter, T. (2011). Auf dem Weg zu einer Theorie lernseits von Unterricht. In M. Meseth, M. Proske \& F.O. Radtke (Eds.) Zur Bedeutung der Theorie des Unterrichts (pp. 103-129). Bad Heilbrunn: Klinkhardt.

Schratz, M., Schwarz, J. F. \& Westfall-Greiter, T. (2012). Lernen als bildende Erfahrung. Vignetten in der Praxisforschung. Innsbruck: StudienVerlag.

Tallis, R. (2010). Michelangelo’s finger: An exploration of everyday transcendence. London: Atlantic Books.

Taylor-Guthrie, D.K. (Ed.) (1994). Conversations with Toni Morrison. Jackson: University Press of Mississippi.

Tomlinson, C.A. (2003). Fulfilling the promise of the differentiated classroom: Strategies and tools for responsive teaching. Virginia: Association of Supervision and Curriculum Development.

Tomlinson, C.A. (2008). The differentiated school: Making revolutionary changes in teaching and learning. Virginia: Association of Supervision and Curriculum Development.

Tomlinson, C.A. (2011, June). Growing good teachers. Lecture presented at the University of Innsbruck, Innsbruck, Austria. 
van Manen, M. (2011). Phenomonology Online: A resource for phenomenological inquiry. Retrieved from http://www.phenomenologyonline.com/inquiry/methodology/.

van Manen, M. (1991). The tact of teaching: The meaning of pedagogical thoughtfulness. Ontario: The Althouse Press.

van Manen, M. (1990). Researching lived experience: Human science for an action sensitive pedagogy. Albany: The State University of New York Press.

Waldenfels, B. (2002). Bruchlinien der Erfahrung. Phänomenologie, Psychoanalyse, Phänomenotechnik. Frankfurt am Main: Suhrkamp.

Wischer, B. (2012). Individuelle Förderung als pädagogische Nebelbombe: Schultheoretische Provokationen zu programmatischen Fallstricken im aktuellen Heterogenitätsdiskurs. Lecture at the University of Innsbruck, 19. 04. 2012, Innsbruck, Austria. 